\title{
BMJ Open Associations between self-rated health and health behaviour among older adults in Estonia: a cross- sectional analysis
}

\author{
Liili Abuladze, ${ }^{1}$ Nele Kunder, ${ }^{2}$ Katrin Lang, ${ }^{2}$ Sirje Vaask ${ }^{3}$
}

To cite: Abuladze L, Kunder N, Lang $\mathrm{K}$, et al. Associations between self-rated health and health behaviour among older adults in Estonia: a crosssectional analysis. BMJ Open 2017;7:e013257. doi:10.1136/ bmjopen-2016-013257

- Prepublication history and additional material are available. To view these files please visit the journal online (http://dx.doi org/10.1136/bmjopen-2016013257).

Received 29 June 2016 Revised 3 April 2017 Accepted 5 April 2017

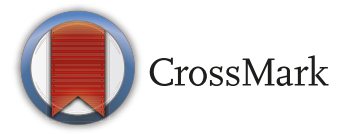

${ }^{1}$ Estonian Institute for Population Studies, School of Governance, Law and Society, Tallinn University, Tallinn, Estonia ${ }^{2}$ Department of Public Health, Faculty of Medicine, University of Tartu, Tartu, Estonia

${ }^{3}$ School of Natural Sciences and Health, Tallinn University, Tallinn, Estonia

Correspondence to Liili Abuladze; liili@tlu.ee

\section{ABSTRACT}

Objectives The population of Estonia has one of the lowest life expectancies and health statuses in Europe. This is reflected in a lower perception of health among older adults. This study focuses on the role of health behaviour (smoking, alcohol consumption, physical activity and nutrition) in self-rated health, accounting for sociodemographic characteristics, activity limitations and long-term illnesses as well as satisfaction with life of older Estonian men and women.

Design We use representative cross-sectional data from Wave 4 of the Estonian Survey of Health, Ageing and Retirement in Europe, conducted mainly in 2011.

Participants Frequencies, $\chi^{2}$ tests and logistic regression models include respondents aged 50 years and older, with no upper age limit $(\mathrm{n}=6660)$.

Results Men have 20\% higher odds ( $\mathrm{Cl} 1.02$ to 1.43 ) of poor self-rated health. Being of foreign origin (OR 1.48; $\mathrm{Cl} 1.24$ to 1.77$)$, having a basic $(2.50 ; \mathrm{Cl} 2.06$ to 3.00$)$ or secondary $(1.71 ; \mathrm{Cl} 1.43$ to 2.04$)$ education, being retired (2.00; $\mathrm{Cl} 1.65$ to 2.44$)$ or staying at home $(1.49 ; \mathrm{Cl} 1.16$ to $1.93)$ and having activity limitations (3.25; $\mathrm{Cl} 2.77$ to 3.80$)$ or long-term illnesses (4.78; $\mathrm{Cl} 4.08$ to 5.60 ) are related to poor self-rated health. Never being involved in vigorous (2.30; Cl 1.90 to 2.79$)$ or moderate physical activity (1.41; $\mathrm{Cl} 1.02$ to 1.94), and consuming legumes and eggs less frequently $(1.25 ; \mathrm{Cl} 1.08$ to 1.45$)$ is associated with poorer self-rated health. Lower satisfaction with life accounts for some of the variation (2.28; $\mathrm{Cl} 1.92$ to 2.71$)$.

Conclusions There is a strong cumulative effect of one's previous life course on the self-rated health of older adults in Estonia, suggesting that public health policies have long-term consequences rather than immediate consequences. Health services supporting health behaviours and targeting vulnerable population groups with specific sociodemographic characteristics and health problems may influence self-rated health for some. Public health services emphasising social activities or psychological aspects may be most successful in improving self-rated health of older Estonians through satisfaction with life.

\section{INTRODUCTION}

The population of Estonia is ageing similarly to other developed countries-it is characterised by increasing life expectancy and

\section{Strengths and limitations of this study}

The study uses data that are sufficiently representative of the $50+$ aged population of Estonia to enable several indicators of health behaviour and sociodemographic groups to be included in the analysis.

- The study uses data from only one wave of the survey, which does not allow for a change in SRH to be observed over time.

the transformation of morbidity and health behaviour patterns. The factors that keep older individuals active longer are important for individual well-being, as they prolong independence, as well as for sustainable social and economic development. Health problems tend to emerge and accumulate in old age; therefore, an ageing population may have increasing health issues in the future. On the other hand, making health-conscious choices may mitigate the effects of chronic diseases, prevent a decrease in activity and help maintain good quality of life in old age. Individuals' own understanding and perception of their health status can influence all of the above, while subjective understanding of health itself is also influenced by different factors.

Both objective health status and awareness of the behavioural factors that influence health have improved considerably over the last couple of decades in Estonia. Estonian life expectancy at the age of 65 years increased from 15.6 years in 2002 to 18.2 years in 2013 for the whole population, although still remaining below the European Union average. ${ }^{1}$ Moreover, the

Estonian gender gap in life expectancy is one of the largest in the world. Those of foreign origin comprise about one-third of the total population of the country and have contributed to the rapid ageing of the population 
as previously numerous young migrants matured. The foreign-origin population has a lower life expectancy and greater prevalence of disability compared with the native-born, exhibiting a morbidity and mortality-related path-dependency characteristic of the Soviet era. ${ }^{2}$

Previous studies of self-rated health (SRH), limitations with regard to daily activities and health behaviour have also shown that Estonia is in a lagging position in terms of these indicators. ${ }^{3-6}$ Estonia has the highest proportion (over 70\%) of people reporting fair or poor SRH compared with other countries in the Survey of Health, Ageing and Retirement in Europe (SHARE); however, these differences have been explained limitedly by lifestyle factors (smoking, alcohol consumption, nutrition and physical activity) and education in a previous study. ${ }^{7}$ Estonia has a rather high level of activity limitations stemming from chronic diseases, with limitations rapidly gaining prevalence after the age of 50 years. ${ }^{5}$ A major political reform aiming to improve services and access to these services for people with activity limitations anddecrease their inactivity in society was started in 2016. The effects of this reform are to be evaluated in the future but due to their high prevalence it is important to consider activity limitations and illnesses when studying SRH. People in the Baltic States have evaluated their health below that of Finns' evaluations more often, reflecting the psychological and social context of the Baltic States. ${ }^{8}$ By including satisfaction with life when studying Estonian subjective health outcomes, thesociopsychologicalbackground would be accounted for.

The population above the age of 80 years, that is, the oldest old, have usually not been included in largescale international population-level studies, especially in Estonia. In the context of ageing societies, this group deserves more attention. Not assuming homogeneity among old adults and focusing on the 50+ aged population allow one to distinguish how different people age, starting from a period in life when most people are active and healthy.

Health is a term that covers a wide spectrum of conditions and is interpreted differently by various individuals and institutions. The 1948 WHO definition emphasises the cognitive and social elements of health. ${ }^{9}$ The SRH indicator is easy to interpret because it includes the cognitive and social elements and provides an overview of health by asking a single question. It is considered a good predictor of morbidity and mortality and is associated with health behaviour. ${ }^{10-12}$ Perceiving oneself as a healthy individual enables one to participate fully in society longer, which is crucial to ageing populations. We assume that various elements can improve SRH. In this article, the subjective measure of SRH is the main dependent variable, while the sociodemographic, objective health status, health behaviour variables and satisfaction with life are the determinants or confounders of SRH in old age.

The main objective of the paper is to analyse the situation of older Estonians' SRH, accounting for sociodemographic characteristics, relatively low objective health status, relatively low satisfaction with life and health behaviour characteristics of these people within one analysis. Secondly, the sub-purpose of the article is to investigate SRH differentials by group characteristics: gender, origin and health behaviour aspects in order to explain findings. Focusing on SRH allows us to evaluate whether the Estonian older population has accepted modern health approaches or if people are described by the "former health characteristics". Estonia's interesting case study may prove to be a useful example for other countries where people have experienced a Soviet (or similar) health system, but that have gone or still have to go through a transition to a modern health system that places more emphasis on an individual's own responsibility (in terms of health awareness and behaviour) in maintaining their health. Out-of-pocket payments have been kept stable at around $20 \%$ over the last 15 years in Estonia. Most of these costs are spent on pharmaceuticals or medication. ${ }^{1314}$ There are no surveys that evaluate the change in out-of-pocket payments in comparison to the Soviet period. However, it should be kept in mind that the Soviet period was characterised by a large informal economy sector (these proportions even increased in the 1990s but have since decreased ${ }^{1516}$ ), meaning that people paid out of their pocket informally to receive various services, especially in healthcare. Therefore, the Soviet system was the basis for creating larger inequality in healthcare usage and health outcomes than the current system.

\section{DATA AND METHODS}

SHARE was started in 2004 to study paths of ageing of people aged 50 years and older in several European countries (and Israel). SHARE is an ex-ante harmonised cross-country survey. The questionnaire has been designed by a core team consisting of international experts of health, employment, social networks, and so on. It is largely based on the US Health and Retirement Study and the English Longitudinal Study of Ageing with multidisciplinarity, cross nationality and longitudinality being the main principles of including questions. ${ }^{1718}$

SHARE Wave 4 was the first time this survey was conducted in Estonia, therefore no previous information on the country was available for analysis. To map the initial situation of SRH of older Estonians, we use Estonian data from the SHARE Wave 4 (or Estonian Wave 1). The Estonian SHARE survey uses a randomised sample stratified by age, sex, origin (native born or foreign born) and regional distribution as of 1 January 2010. In addition, the Estonian sample was cross checked with the death register prior to the start of fieldwork to account for deaths that occurred after sampling. The sample is representative of the $50+$ aged population of the country and provides a sufficient number of cases for subgroups to be analysed. In total, 6828 people responded, resulting in a response rate of $58 \%$ for Estonia. The sample size and the response rate were relatively high compared with 
other countries participating in this wave. ${ }^{18}$ This response rate is closeto,but below the weighted average of response rates $(61.8 \%)$ of countries participating in Wave $1 .{ }^{19} \mathrm{We}$ use a cross-sectional study design and our analysis is limited to only one wave. Since the data collection falls into a period following the economic crisis, this analysis can be used as a benchmark for studying the effect of any political interventions on older adults' health outcomes in the future. Until July 2011, SHARE was reviewed and approved by the Ethics Committee of the University of Mannheim. Since then, the Ethics Council of the Max Planck Society for the Advancement of Science (MPG) is responsible for ethical reviews and the approval of the study.

The data used in this analysis are based on the main survey respondents and their partners aged 50 and above who were interviewed in the Wave 4 of the SHARE study in Estonia mainly in 2011 (total $\mathrm{n}=6828$ ). Those aged below 50 years (eg, some partners)as well as those who had no response, refused to respond or did not know how to respond to the SRH indicator were excluded from the analysis $(n=168)$. With regard to the other variables, the analysis included missing values and 'don't know' responses. The final sample for our analysis after excluding the non-responses was 6660 people (main survey respondents: 4631, and their partners, 2029).

SRH is the main outcome of the analysis, and it is ranked according to a five-point scale: (1) 'excellent', (2) 'very good', (3) 'good', (4) 'fair' and (5) 'poor'. We condensed the scale into two categories: good (1-3) and poor (4-5). This grouping is similar to that used in other studies $^{720} 21$ and was well suited for handling the Estonian satisfaction scales, which are somewhat negative in relation to other Europeans. ${ }^{8}$

The demographic variables in the analysis included sex, age (50-64 years, $65-79$ years and $80+$ years), origin (born in Estonia or not), partnered (lives with a partner in the same household or not, regardless of official marital status), highest level of education achieved (basic, (post) secondary or tertiary) and employment status (employed, retired or at home (ill, homemaker and so on)).

The binary objective health status variables control for the existence and level of activity limitations (according to the Global Activity Limitation Index ${ }^{22}$ ) and long-term illnesses (a self-reported indicator of a chronic illness, long-term health problem or infirmity that has troubled or might trouble the respondent over a period of time). These act as confounding variables, accounting for structural population differences in morbidity patterns, as described above. By including these variables, the effect of other determinants can be evaluated more clearly. Health behaviour is measured by smoking (currently smoking or not currently smoking/never smoked), frequency of alcohol consumption (not at all, 1-2 days per month, 1-4 days per week and 5-7 days per week), frequency of vigorous or moderate physical activity, frequency of consumption of vegetables and fruits (daily or less), fish,chicken and meat and dairy products. Eating legumes and egg products is divided into two categories: daily/3-6 times per week, and less, according to the recommendations of the Estonian food-based dietary guidelines. ${ }^{23}$ Consuming different sources of protein is important in order to avoid protein-energy malnutrition, a public health problem that is common in countries with a high proportion of rural residents and among older people. ${ }^{24}{ }^{25}$ Because this could influence subjective measures such as SRH, our models also account for satisfaction with life (a binary variable indicating low $(0-5$ points) or high (6-10) levels).

The SRH distributions according to the sociodemographic and health-related variables are given in frequencies and percentages. A $\chi^{2}$ test was used for comparing SRH between variables. Associations between poor SRH and the health-related variables were estimated using binary logistic regression models. It is based on the probability of a certain characteristic being true or not given the values of explanatory variables. We included sociodemographic factors together in the model first, followed by two objective health indicators, followed by health behaviour indicators and finally satisfaction with life to see how SRH changes with each set of variables. We present and interpret the final adjusted model including all variables. The data were analysed by means of the Stata V.11 statistical package.

\section{RESULTS \\ Mapping poor SRH}

The proportion of older adults $(50+$ years $)$ in Estonia rating their health as fair or poor is one of the largest in Europe (70.7\% according to the SHARE Wave 4, figure 1$)$. The situation is the reverse in Switzerland, Denmark and the Netherlands, where more than $70 \%$ of older adults consider their health to be good.

The proportion of individuals who rated their health as poor was similar for men and women in Estonia-approximately two-thirds-although the figure was slightly higher

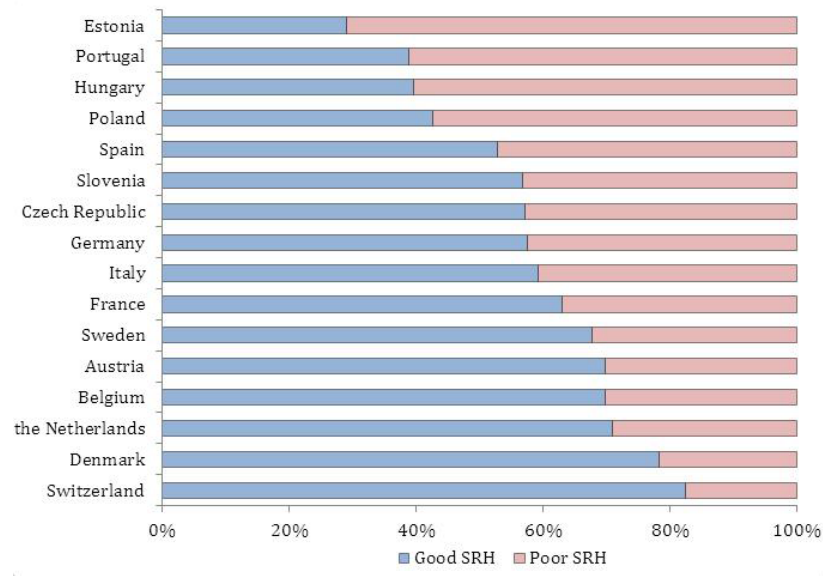

Figure 1 Distribution of good and poor self-rated health in the countries of Europe (\%). Blue bars refer to good selfreported health and pink bars refer to poor self-reported health. Source: SHARE, Wave 4, 2011. 


\begin{tabular}{|c|c|c|c|c|}
\hline Variables & $\begin{array}{l}\text { Poor } \\
\text { SRH }\end{array}$ & $\%$ (row) & Total & $\%$ (column) \\
\hline \multicolumn{5}{|l|}{ Sex } \\
\hline Male & 1914 & 70.7 & 2706 & 40.6 \\
\hline Female & 2855 & 72.2 & 3954 & 59.4 \\
\hline \multicolumn{5}{|l|}{ Age (years) } \\
\hline $50-64$ & 1776 & 60.3 & 2946 & 44.2 \\
\hline $65-79$ & 2238 & 77.9 & 2872 & 43.1 \\
\hline $80+$ & 755 & 89.7 & 842 & 12.7 \\
\hline \multicolumn{5}{|l|}{ Country of birth } \\
\hline Estonia & 3391 & 68.6 & 4945 & 74.3 \\
\hline Other & 1378 & 80.4 & 1715 & 25.7 \\
\hline \multicolumn{5}{|l|}{ Partner in household } \\
\hline Yes & 3175 & 69.8 & 4547 & 68.3 \\
\hline No & 1594 & 75.4 & 2113 & 31.7 \\
\hline \multicolumn{5}{|l|}{ Education } \\
\hline Higher & 747 & 53.7 & 1386 & 20.8 \\
\hline (Post) secondary & 1709 & 69.8 & 2448 & 36.8 \\
\hline Basic & 2302 & 81.7 & 2814 & 42.2 \\
\hline Missing values & & & 12 & 0.2 \\
\hline \multicolumn{5}{|l|}{ Employment status } \\
\hline Employed & 1084 & 49.5 & 2188 & 32.9 \\
\hline Retired & 3113 & 83.0 & 3752 & 56.3 \\
\hline $\begin{array}{l}\text { Other (homemaker, } \\
\text { ill, etc) }\end{array}$ & 559 & 79.1 & 706 & 10.6 \\
\hline Missing values & & & 14 & 0.2 \\
\hline \multicolumn{5}{|l|}{ Activity limitations } \\
\hline No & 1247 & 45.9 & 2714 & 40.8 \\
\hline $\begin{array}{l}\text { Yes (severely + } \\
\text { moderately limited) }\end{array}$ & 3517 & 89.3 & 3939 & 59.1 \\
\hline Missing values & & & 7 & 0.1 \\
\hline \multicolumn{5}{|l|}{ Long-term illnesses } \\
\hline No & 574 & 33.5 & 1714 & 25.7 \\
\hline Yes & 4193 & 84.8 & 4943 & 74.2 \\
\hline Missing values & & & 3 & 0.1 \\
\hline
\end{tabular}

SHARE, Survey of Health, Ageing and Retirement in Europe; SRH, self-rated health.

for women $(72.2 \%)$ than men $(70.7 \%)$ (table 1$)$. The proportion of people with poor SRH increased with age: in the youngest age group (50-64 years) $60.3 \%$ of respondents rated their health as poor, whereas in the two older age groups more than three-quarters of respondents did so. More of the foreign-born reported poor health $(80.4 \%)$ than did the native-born $(68.6 \%)$. People living with a partner rated their health as poor somewhat less often $(69.6 \%)$ than those living without a partner $(75.4 \%)$. The proportion of those reporting poor health decreased with their level of education $(81.7 \%$ with basic education, $69.8 \%$ with secondary education and $53.7 \%$ with tertiary education). There are major differences in the proportions of poor SRH between employment status groups-approximately half of those who were working reported poor health compared with four-fifths of retired people.

Nearly half $(45.9 \%)$ of those who do not have activity limitations evaluate their health as poor as opposed to the majority $(89.3 \%)$ of those who do. Differences in SRH also exist among people with long-term illnesses: the majority $(84.8 \%)$ of those who have such illnesses consider their health poor as compared with one-third of respondents who do not.

Smokers reported a slightly lower proportion of poor health than non-smokers (68.8\% vs $72.3 \%$; table 2 ). Regarding alcohol use, abstainers had a higher proportion $(82.1 \%)$ of poor SRH than people drinking somewhat frequently $(59.2 \%-65.8 \%)$. There appears to be a positive relationship between physical activity and SRH-both moderate and vigorous physical activity are related to better SRH-and the frequency of physical activity is directly related to SRH in a dose-response relationship.

There was a lower proportion of people with poor SRH among those who eat fruits and vegetables, dairy products, meat, chicken and fish on a daily basis, and also among those who eat legumes and eggs daily or 3-6 times a week compared with those who eat these products less often. Finally, there are more people reporting poor health among those with lower levels of satisfaction with life than those with higher levels, although the latter percentage is quite high as well $(85.8 \%$ and $64.6 \%$, respectively).

\section{Associated factors with SRH}

After adjusting for all variables in binary logistic regression models, older Estonian men report poorer health than women (table 3). 'Good SRH declines with age and the overall effect is statistically significant, but none of the differences between age groups remain statistically significant from the reference group (aged 50-64 years) in the final regression model. ${ }^{\dagger}$ The foreign-born population reports poorer health than the native Estonians (OR 1.48).

Those with basic education have more than twice as high odds of reporting poor health than those with higher education. Older people with (post) secondary education have an OR of 1.71 of reporting poor health than those with higher education. Retired people have also twice as high odds of reporting poor health than those who are employed. Those with activity limitations and long-term

\footnotetext{
*To evaluate the effect of the age variable to the model and to SRH, a likelihood ratio test was calculated. Adding age improved the model fit significantly compared with the previous, simpler model with only gender-the likelihood ratio test comparing the estimates of the two models indicated to bestatistically significantly different.

${ }^{\dagger}$ First, controlling for only sociodemographic and health indicators, there were no statistically significant differences in SRH between men and women. After including vigorous physical activity, the gender difference became statistically significant. Also, initially statistically significant differences in SRH between the ages 50-64 and 65-79 years became insignificant when activity limitations were controlled for, and they became insignificant compared with the oldest old group after vigorous physical activity was included in the model.
} 
Table 2 Distribution of poor SRH by health-related variables among the population aged $50+$ years in Estonia, 2011 (SHARE Wave 4, Estonia, $\mathrm{n}=6660$ )

\begin{tabular}{|c|c|c|c|c|}
\hline Variables & $\begin{array}{l}\text { Poor } \\
\text { SRH }\end{array}$ & $\%$ (row) & Total & $\%$ (column) \\
\hline \multicolumn{5}{|l|}{ Smoking } \\
\hline No & 3848 & 72.3 & 5325 & 79.9 \\
\hline Yes & 910 & 68.8 & 1322 & 19.9 \\
\hline Missing values & & & 13 & 0.2 \\
\hline \multicolumn{5}{|l|}{$\begin{array}{l}\text { Alcohol } \\
\text { consumption }\end{array}$} \\
\hline Not at all & 2218 & 82.1 & 2702 & 40.6 \\
\hline $\begin{array}{l}1-2 \text { days per } \\
\text { month }\end{array}$ & 1793 & 65.8 & 2723 & 40.9 \\
\hline $\begin{array}{l}\text { 1-4 days per } \\
\text { week }\end{array}$ & 583 & 59.2 & 982 & 14.7 \\
\hline $\begin{array}{l}\text { 5-7 days per } \\
\text { week }\end{array}$ & 158 & 63.6 & 232 & 3.5 \\
\hline Missing values & & & 21 & 0.3 \\
\hline \multicolumn{5}{|l|}{$\begin{array}{l}\text { Vigorous physical } \\
\text { activity }\end{array}$} \\
\hline $\begin{array}{l}\text { More than once } \\
\text { a week }\end{array}$ & 1381 & 56.7 & 2434 & 36.6 \\
\hline Once a week & 576 & 64.7 & 886 & 13.3 \\
\hline $\begin{array}{l}1-3 \text { times per } \\
\text { month }\end{array}$ & 429 & 71.6 & 599 & 9 \\
\hline $\begin{array}{l}\text { Very seldom/not } \\
\text { at all }\end{array}$ & 2367 & 86.9 & 2722 & 40.8 \\
\hline Missing values & & & 19 & 0.3 \\
\hline \multicolumn{5}{|l|}{$\begin{array}{l}\text { Moderate physical } \\
\text { activity }\end{array}$} \\
\hline $\begin{array}{l}\text { More than once } \\
\text { a week }\end{array}$ & 3003 & 66.1 & 4538 & 68.1 \\
\hline Once a week & 613 & 74.8 & 817 & 12.3 \\
\hline $\begin{array}{l}1-3 \text { times per } \\
\text { month }\end{array}$ & 261 & 80.1 & 326 & 4.9 \\
\hline $\begin{array}{l}\text { Very seldom/not } \\
\text { at all }\end{array}$ & 879 & 91.2 & 964 & 14.5 \\
\hline Missing values & & & 15 & 0.2 \\
\hline
\end{tabular}

\section{Eating fruits and} vegetables

\begin{tabular}{|lrrrr|}
\hline Daily & 3118 & 69.1 & 4503 & 67.6 \\
\hline Less than daily & 1636 & 76.3 & 2141 & 32.2 \\
\hline Missing values & & & 16 & 0.2 \\
\hline
\end{tabular}

\section{Eating dairy products}

\begin{tabular}{|lrrrr|} 
Daily & 3219 & 70.5 & 4570 & 68.6 \\
\hline Less than daily & 1535 & 74.0 & 2073 & 31.1 \\
\hline Missing values & & & 17 & 0.3 \\
\hline
\end{tabular}

Eating meat, fish or chicken

\begin{tabular}{|c|c|c|c|c|}
\hline Variables & $\begin{array}{l}\text { Poor } \\
\text { SRH }\end{array}$ & $\%$ (row) & Total & $\%$ (column) \\
\hline Daily & 2562 & 69.2 & 3701 & 55.6 \\
\hline Less than daily & 2194 & 74.5 & 2944 & 44.2 \\
\hline Missing values & & & 15 & 0.2 \\
\hline \multicolumn{5}{|l|}{$\begin{array}{l}\text { Eating legumes } \\
\text { and eggs }\end{array}$} \\
\hline $\begin{array}{l}\text { Daily or } 3-6 \\
\text { times per week }\end{array}$ & 1566 & 68.2 & 2295 & 34.5 \\
\hline Less often & 3183 & 73.3 & 4341 & 65.2 \\
\hline Missing values & & & 24 & 0.4 \\
\hline \multicolumn{5}{|l|}{$\begin{array}{l}\text { Satisfaction with } \\
\text { life }\end{array}$} \\
\hline $\begin{array}{l}\text { Lower (0-5 } \\
\text { points) }\end{array}$ & 1781 & 85.8 & 2076 & 31.2 \\
\hline $\begin{array}{l}\text { Higher (6-10 } \\
\text { points) }\end{array}$ & 2817 & 64.6 & 4363 & 65.5 \\
\hline Missing values & & & 221 & 3.3 \\
\hline
\end{tabular}

SHARE, Survey of Health, Ageing and Retirement in Europe; SRH, self-rated health.

illnesses have poorer SRH than those without (OR 3.25 and 4.78 , respectively).

Smokers rate their health as poorer than non-smokers (OR 1.23); however, it is statistically insignificant after satisfaction with life is included in the model. An adjusted model indicated a 'protective effect' of alcohol consumption on SRH-those consuming alcohol more frequently rated their health as better than those abstaining from alcohol. However, the SRH of those consuming alcohol on an almost daily basis (5-7 times per week) did not differ significantly from those abstaining.

More frequent vigorous physical activity is also associated with better SRH; those who never or rarely engage in such activity report poorer health (OR that is 2.30 times higher than for those who engage in it more than once a week, table 3). Similarly, people who rarely or never participate in moderate physical activity have poorer SRH than those who do so frequently (OR 1.41).

Those who consume fruits and vegetables on a less than daily basis rate their health as poorer than daily consumers (OR 1.17); however, the difference is not statistically significant after accounting for satisfaction with life. In fact, with regard to dietary behaviour, only those who eat legumes and eggs less than daily or 3-6 times a week are significantly as likely (OR 1.25) to have poor SRH.

Finally, those with lower satisfaction with life report poorer health (OR 2.28).

\section{Whom should public health interventions target?}

Since the adjusted model indicated that men rate their health as poorer than women, we sought to examine this gender difference more closely. Differentiating the results by gender revealed that those of foreign origin 
Table 3 ORs for poor self-rated health by demographic, objective health status and health behaviour variables among Estonians aged 50+ years, 2011 (SHARE Wave 4, Estonia, $\mathrm{n}=6$ 660)

\begin{tabular}{|c|c|c|c|}
\hline \multirow[b]{2}{*}{ Variables } & \multicolumn{3}{|c|}{ Adjusted model } \\
\hline & OR & $95 \% \mathrm{Cl}$ & $\begin{array}{l}\text { Overall } \\
p \text { value }\end{array}$ \\
\hline Sex & & & 0.051 \\
\hline Men & 1 & & \\
\hline Women & 0.83 & 0.70 to 0.98 & \\
\hline Age (years) & & & $<0.0001$ \\
\hline $50-64$ & 1 & & \\
\hline $65-79$ & 1.04 & 0.86 to 1.28 & \\
\hline $80+$ & 1.31 & 0.94 to 1.83 & \\
\hline Country of birth & & & $<0.0001$ \\
\hline Estonia & 1 & & \\
\hline Other & 1.48 & 1.24 to 1.77 & \\
\hline Partner in household & & & 0.206 \\
\hline Yes & 1 & & \\
\hline No & 0.91 & 0.77 to 1.08 & \\
\hline Education & & & $<0.0001$ \\
\hline Higher education & 1 & & \\
\hline Secondary education & 1.71 & 1.43 to 2.04 & \\
\hline Basic education & 2.50 & 2.06 to 3.00 & \\
\hline Employment status & & & $<0.0001$ \\
\hline Employed & 1 & & \\
\hline Retired & 2.00 & 1.65 to 2.44 & \\
\hline Other (homemaker, ill, etc) & 1.49 & 1.16 to 1.93 & \\
\hline Activity limitations & & & $<0.0001$ \\
\hline None & 1 & & \\
\hline $\begin{array}{l}\text { Yes (severely+moderately } \\
\text { limited) }\end{array}$ & 3.25 & 2.77 to 3.80 & \\
\hline Long-term illnesses & & $<0.0001$ & \\
\hline None & 1 & & \\
\hline Yes & 4.78 & 4.08 to 5.60 & \\
\hline Smoking & & & 0.225 \\
\hline $\begin{array}{l}\text { Not smoking+never } \\
\text { smoked }\end{array}$ & 1 & & \\
\hline Yes & 1.23 & 0.93 to 1.35 & \\
\hline Alcohol consumption & & & $<0.0001$ \\
\hline Never & 1 & & \\
\hline $1-2$ days per month & 0.73 & 0.62 to 0.87 & \\
\hline 1-4 days per week & 0.65 & 0.52 to 0.82 & \\
\hline 5-7 days per week & 0.75 & 0.51 to 1.11 & \\
\hline Vigorous physical activity & & & $<0.0001$ \\
\hline More than once a week & 1 & & \\
\hline Once a week & 1.56 & 1.26 to 1.93 & \\
\hline 1-3 times per month & 1.61 & 1.25 to 2.08 & \\
\hline
\end{tabular}

Continued
Table 3 Continued

\begin{tabular}{|c|c|c|c|}
\hline \multirow[b]{2}{*}{ Variables } & \multicolumn{3}{|c|}{ Adjusted model } \\
\hline & OR & $95 \% \mathrm{Cl}$ & $\begin{array}{l}\text { Overall } \\
p \text { value }\end{array}$ \\
\hline Rarely/never & 2.30 & 1.90 to 2.79 & \\
\hline Moderate physical activity & & & 0.103 \\
\hline More than once a week & 1 & & \\
\hline Once a week & 1.00 & 0.79 to 1.27 & \\
\hline 1-3 times per month & 0.82 & 0.57 to 1.18 & \\
\hline Rarely/never & 1.41 & 1.02 to 1.94 & \\
\hline Eating fruits and vegetables & & & 0.59 \\
\hline Daily & 1 & & \\
\hline Less than daily & 1.17 & 0.99 to 1.34 & \\
\hline Eating dairy products & & & 0.573 \\
\hline Daily & 1 & & \\
\hline Less than daily & 1.04 & 0.89 to 1.22 & \\
\hline Eating legumes and eggs & & & 0.006 \\
\hline $\begin{array}{l}\text { Daily or 3-6 times per } \\
\text { week }\end{array}$ & 1 & & \\
\hline Less often & 1.25 & 1.08 to 1.45 & \\
\hline $\begin{array}{l}\text { Eating meat, chicken and } \\
\text { fish }\end{array}$ & & & 0.409 \\
\hline Daily & 1 & & \\
\hline Less than daily & 0.94 & 0.81 to 1.10 & \\
\hline Satisfaction with life & & & $<0.0001$ \\
\hline Higher (6-10 points) & 1 & & \\
\hline Lower (0-5 points) & 2.28 & 1.92 to 2.71 & \\
\hline
\end{tabular}

and the oldest age groups are the most vulnerable groups among women (see online supplementary appendix 1). Women are also not as frequently involved in physical activity; they have a higher prevalence of activity limitations and long-term illnesses. Among men, however, poor SRH was more prevalent among those with lower education, those who consume alcohol and use tobacco more frequently, and who eat fruits, vegetables and dairy products less frequently.

Because those of foreign origin consistently manifested poorer health outcomes, also confirmed by our analysis, we examined SRH and the main variables separately by origin. There are more people consuming fruits and vegetables on a daily basis among the foreign-origin population than the native population. The prevalence of smoking is also lower among the former. However, people of foreign origin show more frequent alcohol consumption, less frequent consumption of dairy products, legumes and eggs, as well as less physical activity. No educational differences in SRH outcomes emerged between the two populations.

In terms of dietary behaviour, men, those with a basic level of education and those staying at home, are most vulnerable to having poor SRH. Closer examination 
reveals that respondents who rarely eat dairy products, meat, chicken, fish, legumes and eggs (12.3\% of respondents or 817 people,see onlinesupplementary appendix 2) have a higher risk of protein-energy malnutrition.

With regard to physical activity, the groups most vulnerable to poor SRH are individuals who are not involved in moderate physical activity, women, those of foreign origin, those with basic education and retirees.

\section{DISCUSSION}

Our analysis describes differences in SRH among older adults, whose health tends to be worse than that of younger adults. Although the 80+ aged population's SRH was somewhat poorer than that of younger olds, no significant age differences remained after adjusting for all variables. This indicates that these variables account for the variation in SRH among the different age groups of older Estonians, and that path dependency from the Soviet time in terms of SRH is similar between all the age groups of older Estonians. Modelling with 75+ years and $80+$ years age groups yielded similar results. The similar path dependency for older people in this case indicates that despite specificities of the life course phases and each individual's own experiences, the experienced environment and behaviour manifest in a similar way for all Estonian older adults, at least when age is concerned.

Higher education seems to have a protective effect on health, confirming previous results. A novel global finding is that Estonian men have poorer SRH than women, after adjusting for all variables. Previous findings on gender differences show mixed results for Estonia, with better SRH for women, ${ }^{4}$ no difference ${ }^{26}$ and better SRH for men $^{27}$; however, all of these studies focus solely on the adult population. A gender difference in outcomes may be an indication of different cohorts having opposite effects on the gender variation in health behaviour and perception of health. Therefore, the mechanisms might be reversed for the older and general adult populations, with men being more 'vulnerable' in terms of SRH and health behaviour outcomes in old age. Gender differences in health behaviour emerge among older Estonians, which may be related to the different morbidity structures among demographic groups, as previously identified. ${ }^{2}$ Closer examination of gender differences in this paper hints at low physical activity being the main concern for women (which may be connected to a higher prevalence of activity limitations and illnesses), whereas alcohol and tobacco consumption as well as less frequent use of fruit, vegetables and dairy products are a concern for men. It is essential to figure out which health intervention actions would be helpful in increasing SRH of lower educated men. In terms of public health interventions, the results suggest more targeted approaches for different genders, taking into account specific health issues of both men and women. Alternatively, as the observed cohorts get older or die, and healthier cohorts enter old age, the health indicators of the total population are likely to improve.
In addition, the lower health status of theforeign-originpopulation in Estonia was also confirmed in terms of poorer SRH. It is mainly due to the fact that the foreign-origin population consists of older women that have larger proportions of activity limitations and long-term illnesses. Some of the differences in the health behaviour may explain these outcomes, specifically,more frequent use of alcohol, less frequent consumption of dairy products, legumes and eggs, as well as less participation in physical activity among the foreign-origin people.Educational differences do not explain the variation in outcomes; however, there might be differences in the type of health services and health-related information that people have access to-either because of doctors that people from different origin visit or through information sources (educational content, media and networks), which we did not examine. In addition, the economic sector and occupational structure differ by origin in Estonia; ${ }^{28}$ further analysis could identify their role in health outcomes as well.

The presence of a partner usually implies the availability of emotional support, which tends to have a positive impact on health outcomes. Our analysis did not find any difference in SRH between those living with or without a partner. However, this result cannot be interpreted as valid for older people living alone as the indicator simply measures the presence or absence of a partner in the same household. We also modelled official marital status as opposed to partnership status, but the results were not remarkably different. These results may be somewhat biased because both partners in a household were included in the analysis.

Activity limitations and long-term illnesses had the largest role in explaining SRH differentials among older Estonians. This is partly driven by the foreign-origin population. Secondly, the results suggest that accumulated health status plays a large role in defining SRH compared with health behaviour factors of a current period in one's life course. Therefore, if ageing populations will include more people with activity limitations, then specific policies and services have to be implemented in order for these illnesses not to become barriers in participating in society. Although a relevant major political reform was started in Estonia in 2016, addressing people with disabilities and activity limitations, it is not yet clear how it may soothe the situation of the most severely limited people whose activityand subjective health indicators are hindered most likely due to low objective health status.

Differences resulting from some health behaviour factors did emerge, implying that for some older people it is possible to influence SRH through changing health behaviour. Eating fruit, vegetables, legumes and eggs less frequently is associated with poor $\mathrm{SRH}$, after adjusting for sociodemographic and objective health status indicators. Consuming legumes and eggs remained statistically significant after adjusting for satisfaction with life, indicating that some protein-energy malnutrition exists among the older population, and it affects SRH negatively. Smoking and engaging in less physical activity were also associated 
with poor SRH, confirming previous knowledge of their harmful effects. However, the statistical significance disappeared for smoking when satisfaction with life was included in the model, decreasing the role of smoking in SRH among older Estonian adults. Our analysis did not investigate causality; therefore, our findings for physical activity may reflect the fact that people with lower health status and lower SRH may be less likely to be active.

An interesting feature of the Estonian results is that those abstaining from alcohol have better SRH after adjusting for all variables, which is somewhat contradictory to previous findings that moderate alcohol consumption has a positive effect on health. On closer examination, almost $83 \%$ of this group was found to have severe limitations or long-term illnesses (see online supplementary appendix $3)$. Therefore, the latter group have reported a negative outcome due to their health problems, indicating that people with poorer health are less likely to drink alcohol, and it suggests that causality runs in the opposite direction-this group's poor SRH stems from serious existing health problems. Also, the group of people with the most frequent alcohol use (5-7 times per week) did not differ significantly from abstainers, perhaps due to including a relatively small number of people.

Older Estonian adults are diverse in terms of health behaviour, treatment and institutional settings; most come from a social setting that did not emphasise preventive practices or a personal role in maintaining one's health and that reflects in their current objective and subjective health outcomes. This suggests a relatively strong role of previous environment, policies and behaviour and a path dependency on these factors. There seems to be a strong cumulative effect of one's previous life course on the SRH of older adults in Estonia, although the SRH indicator was analysed at only one point in time. Therefore, public health policies targeting healthy behaviour should start early on in terms of a person's age, and they should be consistent, suggesting that public health policies have long-term consequences rather than immediate consequences. Satisfaction with life decreases the effect of some of the health behaviour variables, implying that part of the poor SRH is due to low motivation of older adults. This indicates that through influencing subjective well-being indicators, those older adults who have less severe limitations and illnesses may also be more likely to change their health behaviour, leading to better physical health outcomes in their current period of life. Public health policies should consider regular screening of older Estonians with activity limitations and long-term illnesses starting from a certain age to monitor nutritional behaviour. The relatively large group at high risk of protein-energy malnutrition would benefit from regular monitoring of nutritional status when visiting general practitioners or nurses in primary care. Better systemic tools and instruments should be developed with regard to monitoring health behaviour, especially nutrition in order to guide home healthcare nurses in their consultation work. It would be possible to influence health behaviour and SRH if vulnerable groups and risky behaviour were accurately identified and targeted separately.

Generally, non-response concerns younger respondents who are often unavailable for interviewing. In Wave 4 in Estonia, the responses were slightly under-represented among the youngest ( $50-54$ years) and oldest ( $85+$ years) age groups, especially among men, but slightly over-represented among other age groups. ${ }^{29}$ Therefore, it is possible that SRH of younger old who report better SRH and oldest old who are expected to report worse SRH are slightly under-reported in the Estonian SHARE, but they balance each other out. On the other hand, Estonia has been characterised by high mortality compared with other European countries which may have influenced the selection of people with certain health characteristics into this survey in the first place. Overall, given that different factors tend to balance out effects, we conclude that SRH in SHARE represents the health of the 50+ aged Estonian population rather well. We conclude that the results are generalisable to the population of Estonia aged 50 years and older as the survey sample was stratified by sex, age, origin and regional distribution. In future analyses, it would be important to evaluate the effect of the retention rate on health outcomes by different factors.

Acknowledgements Dolores Lindsay and Kristiina Varrone reviewed the language of the manuscript.

Contributors LA and NK conducted statistical analyses of the data. LA authored the paper. NK, KL and SV critically reviewed and contributed to the manuscript.

Competing interests None declared.

Ethics approval Until July 2011, Survey of Health, Ageing and Retirement in Europe (SHARE) was reviewed and approved by the Ethics Committee of the University of Mannheim. Since then, the Ethics Council of the Max Planck Society for the Advancement of Science (MPG) is responsible for ethical reviews and the approval of the study.

Provenance and peer review Not commissioned; externally peer reviewed.

Data sharing statement To access SHARE data, data access approval is needed from the SHARE team, see more information on the project website: . For the dataset and syntax used for this analysis, contact Liili Abuladze.

Open Access This is an Open Access article distributed in accordance with the Creative Commons Attribution Non Commercial (CC BY-NC 4.0) license, which permits others to distribute, remix, adapt, build upon this work non-commercially, and license their derivative works on different terms, provided the original work is properly cited and the use is non-commercial. See: http://creativecommons.org/ licenses/by-nc/4.0/

(c) Article author(s) (or their employer(s) unless otherwise stated in the text of the article) 2017. All rights reserved. No commercial use is permitted unless otherwise expressly granted.

\section{REFERENCES}

1. Eurostat electronic database: mortality data. http://ec.europa.eu/ eurostat/web/population-demography-migration-projections/deathslife-expectancy-data/main-tables (accessed 24 May, 2016).

2. Sakkeus L, Karelson K. The health transition in Estonia: breaking away from the soviet legacy. In: Hogue N, Swanson D, Opportunities and challenges for applied demography in the 21st century applied demography: Springer, 2012:227-61.

3. Pudule I, Grinberga D, Kadziauskiene K, et al. Patterns of smoking in the baltic republics. J Epidemiol Community Health 1999;53:277-82.

4. Monden CW. Changing social variations in self-assessed health in times of transition? the Baltic States 1994-1999. Eur J Public Health 2005;15:498-503. 
5. Altmets $K$, Puur A, Uusküla A, et al. Self-reported activity limitations among the population aged 20-79 in Estonia: a cross-sectional study. Eur J Public Health 2011;21:49-55.

6. Reile R, Helakorpi S, Klumbiene J, et al. The recent economic recession and self-rated health in Estonia, Lithuania and Finland: a comparative cross-sectional study in 2004-2010. J Epidemiol Community Health 2014;68:1072-9.

7. Eriksen ML, Vestergaard S, Andersen-Ranberg K. Health among Europeans - a cross-sectional comparison of 16 SHARE countries. In: Börsch-Supan A, Brandt M, Litwin $\mathrm{H}$, eds. Et alActive ageing and solidarity between generations in Europe: first results from SHARE after the economic crisis. Berlin: De Gruyter, 2013:149-60.

8. Kasmel A, Helasoja V, Lipand A, et al. Association between health behaviour and self-reported health in Estonia, Finland, Latvia and Lithuania. Eur J Public Health 2004;14:32-6.

9. WHO. Preamble to the Constitution of the World Health Organization as adopted by the International Health Conference, New York, 19-22 June, 1946; signed on 22 July 1946 by the representatives of 61 states (Official Records of the World Health Organization). 1948.

10. Jylhä M, Guralnik JM, Ferrucci L, et al. Is self-rated health comparable across cultures and genders? the journals of gerontology series B. Psychol Sci Social Sci 1998;53:S144-52.

11. Manderbacka K, Lundberg O, Martikainen P. Do risk factors and health behaviours contribute to self-ratings of health? Soc Sci Med 1999;48:1713-20.

12. Bombak AE. Self-rated health and public health: a critical perspective. Front Public Health 2013;1:15.

13. WHO. Health care systems in transition: Estonia, 2000. World Health Organization. Regional Office for Europe. European Observatory on Health Care Systems, 2000.

14. Tervishoiukulud TAI. Koostaja: marika Inno, Mare Ruuge. Tallinn: Tervise Arengu Instituut. Tervisestatistika osakond, 2015.

15. Przychodzen J, Przychodzen WK. Grey market and the income inequalities in the post-socialist economies. SSRN Elect J 2009. https://ssrn.com/abstract=1720583

16. Eesti Konjunktuuriinstituut. Varimajandus Eestis 2011 (elanike hinnangute alusel). Tallinn: Estonian Institute for Economic Research, 2012.

17. Börsch-Supan $A$, Jürges $H$. The survey of health, aging, and retirement in Europe-methodology: Mannheim Research Institute for the Economics of Aging, 2005.
18. Malter F, Börsch-Supan A, Kneip T, eds. SHARE wave 4 innovations \& methodology. Munich: MEA, Max Planck Institute for Social Law and Social Policy, 2013

19. Börsch-Supan $A$, Jürges $H$, eds. The survey of health, ageing and retirement in Europe-methodology. Mannheim: Mannheim Research Institute for the Economics of Aging (MEA), 2005.

20. Kawachi I, Kennedy BP, Glass R, et al. Social capital and self-rated health: a contextual analysis. Am J Public Health 1999;89:1187-93.

21. Zarini GG, Vaccaro JA, Canossa Terris MA, Terris MAC, et al. Lifestyle behaviors and self-rated health: the living for health program. $J$ Environ Public Health 2014;2014:1-9.

22. Jagger $\mathrm{C}$, Gillies $\mathrm{C}, \mathrm{Cambois} \mathrm{E}$, et al. The global activity Limitation Index measured function and disability similarly across european countries. J Clin Epidemiol 2010;63:892-9.

23. Vaask S, Liebert T, Maser M, et al. Eesti toitumis-ja toidusoovitused. Tallinn: Tervise Arengu Instituut, Eesti Toitumisteaduse Selts, 2006.

24. WHO. Keep fit for life: meeting the nutritional needs of older persons. World Health Organization, 2002. http://apps.who.int/ iris/bitstream/10665/42515/1/9241562102.pdf (accessed: 24 May 2016)

25. Nordic Council of Ministries. Nordic nutrition recommendations 2012 integrating nutrition and physical activity. 5th edn. Copenhagen, 2014. https://www.norden.org/en/theme/nordic-nutritionrecommendation/nordic-nutrition-recommendations-2012 (accessed 24 May, 2016).

26. Leinsalu M. Social variation in self-rated health in Estonia: a crosssectional study. Soc Sci Med 2002;55:847-61.

27. Reile R, Leinsalu M. Differentiating positive and negative self-rated health: results from a cross-sectional study in Estonia. Int $J$ Public Health 2013;58:555-64.

28. Puur A, Sakkeus L. Estonia: migrants' labour market experience in the 1990s. report edited by Zh. Zayonchkovskaya. CIS Research Center on Forced Migration, Moscow: Adamant Publishing Company, 1999.

29. Sakkeus L. SHARE ehk uuring rahvastikuvananemisest Eestis. In: Sakkeus L, Leppik L, eds. Pilk hallile alale. SHARE Eesti uuringu esimene ülevaade ja soovitused eakate poliitika kujundamiseks. Tallinn: tallinna likool. , 2016:28, 13. https://www.tlu.ee/public/ SHARE/ 